\title{
Pि-

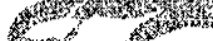 \\ POLITYKA JAPONII WOBEC KRAJÓW EUROPY ŚRODKOWO-WSCHODNIEJ W LATACH DZIEWIĘĆDZIESIĄTYCH - ZARYS UWARUNKOWAŃ
}

Stosunki Japonii z krajami Europy Środkowej i Wschodniej, w tym przede wszystkim z Polską, cechuje niegasnąca fascynacja Japonią w tych krajach, a daleko posunięta ostrożność $\mathrm{w}$ angażowanie się w tak odległym i niestabilnym regionie wśród japońskich polityków i biznesmenów. Japonia jawi się mieszkańcom naszego regionu jako unikalny model intensywnego rozwoju gospodarczego, który podniósł ją do rangi światowego mocarstwa, nie niszcząc jednocześnie kulturowej tożsamości Japończyków. Występuje tam jednak wiele specyficznych zjawisk, utrudniających kopiowanie tego modelu.

Przede wszystkim opiera się on na rodzimej tradycji i z niej wypływa, co zasługuje tym bardziej na uwagę, iż wszystkie kraje naszego regionu w dobie gwałtownych przemian społecznych stają wobec konieczność przebudowy swojej tożsamości, z jednej strony odczuwając potrzebę nawiązania do niszczonej w minionym okresie z premedytacją tradycji własnej, zaś z drugiej stojąc w obliczu nacisku kulturowego krajów wysoko rozwiniętego Zachodu,

Recepcja japońskiego modelu w Polsce i w innych krajach regionu miała raczej powierzchowny charakter. Nie można tu nie wspomnieć $\square$ haśle „budowy drugiej Japonii", rzuconym swego czasu przez Lecha Wałęsę. Uproszczone postrzeganie wschodnioazjatyckiego modelu rozwoju nie jest jednak cechą wyłącznie Polaków. Podobnie postapił Międzynarodowy Bank Odbudowy i Rozwoju (Bank Światowy) w raporcie z 1995 roku, w jakim jego eksperci wprowadzili pojęcie ,interwencji przyjaznej rynkowi" dla wytłumaczenia sukcesu japońskich metod sterowania gospodarką przejętych przez wschodnioazjatyckie „tygrysy". Po załamaniu 1997 r., autorzy raportu znaleźli się w centrum ostrej krytyki, atakującej 
przy okazji, choć bez logicznego związku, pryncypia liberalnej ekonomii, do których Japonia się nie stosuje, a które raport starał się jej na wyrost przypisać'. $\mathrm{Z}$ drugiej strony, niektórzy zwolennicy wolnego rynku piszą o wschodnioazjatyckim kryzysie w kategoriach ,grzechu" nieprzestrzeganie zasad liberalizmu, który musiał pociągnąć za sobą „karę", czyli krach gospodarczy'.

Fascynacja Japonią w Polsce, i innych krajach naszego regionu, nie ogranicza się tylko do spraw gospodarczych i nie pojawiła się nagle u progu naszej transformacji ustrojowej. Sięga ona początków XX wieku, kiedy to Japonia pokonała Rosję, jedno z głównych mocarstw ówczesnego świata, wywołujac tym sensację i podziw, szczególnie wśród ujarzmionych przez Rosję narodów Europy Wschodniej (a, oczywiście, na jeszcze większą skalę w Azji). Stosunki Japonii z Polakami, potem zaś, po odbudowie niezależnej państwowości, z Polska naświetla niedawno wydana praca Ewy PałaszRutkowskiej i Andrzeja Romera Stosunki polsko-japońskie, 1904-1945³. Tutaj spróbujemy przedstawić stan stosunków w okresie najnowszym, to jest w latach dziewięćdziesiatych. Wymaga to jednak krótkiego wprowadzenia do historii polityki japońskiej wobec europejskich krajów socjalistycznych przed upadkiem komunizmu w naszej części świata.

\section{Stosunki polityczne w okresie „zimnej wojny”}

Pierwszym europejskim krajem socjalistycznym, z którym Japonia znormalizowała swoje stosunki po wojnie była, zbuntowana przeciw hegemonii Stalina Jugosławia, która nie wzięła wprawdzie udziału w konferencji pokojowej w San Francisco, już jednak kilka miesięcy później, w marcu 1952 r. podpisała $z$ Tokio memorandum o zakończeniu stanu wojny i nawiązaniu stosunków dyplomatycznych.

Polska i Czechosłowacja uczestniczyły wprawdzie w pracach tej konferencji, jednak idąc za przykładem Związku Sowieckiego, traktatu pokojowego z 8 września 1951 roku nie podpisały, wykorzystując jako pretekst nieobecność przedstawicieli Chińskiej Republiki Ludowej, nieuznawanej wówczas przez państwa Zachodu.

${ }^{1} 1995$ World Bank Annual Report - „Miracle Economy".

Por. Jan Krzysztof Bielecki, „Gazeta Wyborcza" z 6 X 1998 roku.

Ewa Pałasz-Rutkowska, Andrzej T. Romer, Stosunki polsko japońskie 1904-1945, Bellona, Warszawa 1997.
W okresie tym dochodziło jedynie do pewnych nieformalnych kontaktów z lewicową opozycja japońska miẹdzy innymi, podróż po europejskich krajach bloku wschodniego odbyła delegacja parlamentarzystów Japońskiej Partii Socjalistycznej, a japońskie związki zawodowe próbowały interweniować w sprawie zatrzymanych przez siły Guomintangu z Tajwanu polskich statków.

Mimo że Związek Sowiecki nie podpisał traktatu pokojowego w San Francisco i formalnie nadal pozostawał w stanie wojny z Japonią, utrzymywał on w Tokio swoje ,przedstawicielstwo". Powstało ono z przekształcenia radzieckiej misji przy Sojuszniczej Radzie Kontroli Japonii po zakończeniu okupacji. Władze w Tokio de iure nie uznawały przedstawicielskiego charakteru tej misji, w praktyce jednak, tolerowały jej obecność ${ }^{4}$. Dopiero w październiku 1956 r., po długotrwałych negocjacjach, oba państwa zakończyły formalny stan wojny. Japonia uzyskała obietnicę zwrotu dwóch, spośród czterech wysp, których się domagała oraz radzieckie poparcie dla przystąpienia Japonii do ONZ (niezbedne ze wzgledu na posiadanie przez Moskwę prawa weta w Radzie Bezpieczeństwa) $)^{5}$ Ze względu na skomplikowane uwarunkowania ówczesnej sytuacji międzynarodowej, do pełnej realizacji osiągniętego porozumienia nigdy wszakże nie doszło. Japonia dzięki poparciu Moskwy stała się aktywnym członkiem ONZ, ale nie rozwiązany problem terytorialny pozostawił problem stosunków japońsko-sowieckich, a potem japońsko-rosyjskich, otwartym do dziś. Rzutowało to bez wątpienia na politykę Japonii wobec europejskich satelitów Moskwy. Polska była pierwszym z nich, który nawiązał stosunki dyplomatyczne z Japonią. Odpowiednie porozumienie podpisano 8 lutego 1957 roku w Nowym Jorku, podczas sesji Zgromadzenia Ogólnego Narodów Zjednoczonych, pierwszej, w jakiej Japonia uczestniczyła jako członek tej organizacji ${ }^{6} .8$ maja tego samego roku w Londynie Japonia porozumiała się w tej samej sprawie z Czechosłowacją.

Wskazuje to na pewien schematyzm w polityce japońskiej wobec Europy Wschodniej w tym okresie i na traktowanie ich łacznie jako satelickie państwa Moskwy; bez uwzględniania dość zasadniczych różnic między nimi. Przypomnijmy bowiem, iż Polska i Czechosłowacja na początku 1957 roku różniły siẹ bardzo: podczas gdy w Polsce trwało, choć ograniczone względami ,geopolitycznymi", rozliczanie epoki stalinowskiej, to w Pradze niewzruszenie trwała ekipa rządząca starego typu. Dla Japoń-

${ }^{4}$ Józef Kukułka, Historia wspótczesna stosunków międzynarodowych, 1945-1994, Warszawa, PWN 1995, s. 103

${ }^{5}$ Zbiór Dokumentów PISM, nr 10 z 1957 roku, poz. 308

${ }^{6}$ Zbiór Dokumentów PISM, nr 2 z 1957 roku, poz. 22. 
czyków nie miało to jednak znaczenia. Po normalizacji stosunków z Moskwą niemal automatycznie uregulowano stosunki $\mathrm{z}$ dwoma jego największymi europejskimi satelitami. W wewnętrzne spory bloku wschodniego polityka japońska nie zamierzała się wtedy angażować, ani oddziaływać na ich dalszą ewolucję, jak czyniły to USA oraz mocarstwa Europy Zachodniej.

Stopniowe normalizowanie stosunków trwało do końca lat sześćdziesiątych. Japonia nawiązała wówczas stosunki dyplomatyczne ze wszystkimi krajami regionu, z wyjątkiem Albanii, z którą porozumiano się dopiero w 1982 roku.

W latach siedemdziesiątych kierownictwo gierkowskie, w ramach „otwarcia na Zachód", pokładało duże nadzieje na rozwój współpracy gospodarczej z Japonią. W 1970 r. Polska stała się pierwszym partnerem handlowym Japonii w tym regionie, wyprzedzając Jugosławię dzięki importowi z Kraju Kwitnącej Wiśni towarów o wartości 22,4 mln dolarów (w cenach bieżących), i eksportowi o wartości 39,6 mln dolarów (Jugosławia odpowiednio — 40,2 mln dolarów importu z Japonii i 2,9 mln dolarów eksportu $)^{7}$.

W połowie lat siedemdziesiątych udział Polski w japońskim handlu z Europą Środkowo -Wschodnią sięgnął 27,5\% (japoński eksport do Polski: 257 mln dolarów, a import: $80 \mathrm{mln}$ dolarów). Działo się to jednak przy bardzo niskim bezwzględnym i względnym poziomie obrotów. Przy narastającej nierównowadze na korzyść Japonii, jej handel $\mathrm{z}$ europejskimi krajami socjalistycznymi (wraz z Jugosławią i Albanią) osiągnął rozmiar 1,2\% całego japońskiego eksportu i $0,42 \%$ importu, a w liczbach bezwzględnych (ceny bieżące): $683 \mathrm{mln}$ dolarów eksportu i $233 \mathrm{mln}$ dolarów importu —wynik ten nigdy później nie został nawet wyrównany.

W latach osiemdziesiątych Japonia zapisała się w historii Polski dwoma wydarzeniami. W maju 1981 roku, na zaproszenie centrali związkowej Sohyo, kraj ten odwiedziła dziesięcioosobowa delegacja „Solidarności" z Lechem Wałęsą, Zbigniewem Bujakiem, Władysławem Frasyniukiem, Tadeuszem Mazowieckim i Janem Rulewskim. W wizycie tej, zapewne, można doszukiwać się inspiracji idei, która zrodziła wspomniane na wstępie hasło „budowy drugiej Japonii". W grudniu tego samego roku, wkrótce po wprowadzeniu sianu wojennego, o azyl polityczny poprosił Amerykanów polski ambasador w Japonii, Zdzisław Rurarz — był to najbardziej

${ }^{7}$ IMF Direetion of Trade 1970-1976, s. 152-164, Direction of Trade Statistics Yearbook 1987, s. 144-145; Direction of Trade Statisties Yearbook 1989, s. 240-241, Summary Report on Trade of Japan 1990, nr 1, za: Władysław Góralski, „Stosunki Japonii z krajami Europy Środkowo-Wschodniej", Sprawy Międzynarodowe, 1990, nr 9, s. 100. bezpośredni i zarazem szokujacy dla japońskiej opinii publicznej kontakt z dramatycznymi konfliktami politycznymi tamtego czasu w Polsce. Japonia wprowadziła wprawdzie, w odpowiedzi na apel prezydenta Ronalda Reagana sankcje przeciwko Polsce i Związkowi Sowieckiemu, jednakże w przypadku Polski ograniczała je jednak od samego początku do symbolicznego minimum i już w 1985 r., po wizycie ministra spraw zagranicznych Shintaro Abe, można mówić o całkowitej normalizacji stosunków. Rozpoczęły się też rozmowy o restrukturyzacji polskiego zadłużenia wobec Japonii.

\section{Kontakty polityczne po upadku reżimów komunistycznych}

Po przełomie roku 1989, jaki rozpoczął się czerwcowymi wyborami w Polsce, wygranymi przez „Solidarność", Japonia, podobnie jak inne państwa wysoko rozwinięte, zaoferowała Polsce i Węgrom pomoc gospodarczą. 25 października 1989 roku Japonia podpisała z Polską porozumienie o odroczeniu spłaty i restrukturyzacji polskiego zadłużenie zagranicznego w wysokości 396,5 mln dolarów. Decyzja ta była skutkiem rozmów, które toczyły się w ramach Klubu Paryskiego rządów - wierzycieli od sierpnia 1988 roku.

24 listopada 1989 r. Japończycy zaoferowali pakiet pomocy gospodarczej dla Polski, którego ogólna wartość miała się zamknąć sumą $1.050 \mathrm{mld} \mathrm{dol}{ }^{8}$. $150 \mathrm{mln}$ zaangażowano w międzynarodowy fundusz stabilizacyjny dla Polski. Szczegóły pomocy, w postaci nowych kredytów i gwarancji przedstawił podczas swojej wizyty w Polsce i na Węgrzech w styczniu 1990 r. premier Toshiki Kaifu. W jej skład wchodzić miało, między innymi, 25 mln dolarów doraźnego kredytu żywnościowego, $15 \mathrm{mln}$ na program szkolenia menedżerów, 350 mln gwarancji kredytowych dla japońskich eksporterów pragnących ulokować swoje towary na polskim rynku i 500 mln gwarancji japońskiego Banku Eksportowo-Importowego dla prywatnych inwestorów z Japonii ${ }^{9}$.

W listopadzie 1990 roku $\mathrm{z}$ okazji uroczystości intronizacji Cesarza Akihito, wizytę w Japonii złożyła węgierska delegacja państwowa, z prezydentem Arpadem Gonczem. We wrześniu 1991 r. premier Węgier Józef Antali był pierwszym szefem rządu z regionu Europy Środkowo-Wschod-

\footnotetext{
${ }_{9}^{8}$, Kaifu's back from Europe", Tokyo Report, January 17, 1990

9 Japan Times Weekly z 20 stycznia 1990 roku, Far Eastern Eeonomie Review z 18 stycznia 1990
} 
niej, który odwiedził Japonię ${ }^{10}$. W tym samym roku złożył wizytę w Japonii premier Jan Krzysztof Bielecki, rok później minister spraw zagranicznych Polski Krzysztof Skubiszewski, a w grudniu 1992 r. wizytę nieoficjalną były minister spraw zagranicznych Węgier Geza Jeszenszky.

Rok 1992 wyznacza początek kryzysu w stosunkach. Japonii z krajami naszego regionu, szczególnie z Polską. Można znaleźć dwie przyczyny nagłego odstąpienia rządu japońskiego od wspólnej dotychczas polityki Zachodu, zakładającej stopniową redukcję i restrukturyzację polskiego długu zagranicznego. Po pierwsze, Japonia nie chciała stworzyć niebezpiecznego precedensu. Politycy japońscy obawiali się, że zgoda na redukcję polskich długów zachęci inne kraje do wystapienia z podobna prośbą. Głównie myślano o Rosji, której długi były o wiele większe niż Polski i Węgier. Po drugie, obawiano się też, że gospodarki przechodzące transformację ustrojową mogą mieć nadmierne oczekiwania dotyczące japońskich inwestycji i kredytów.

Polskie oczekiwania mogły się Japończykom wydać tym bardziej nadmierne, że podobne potrzeby zgłosiły w tym samym czasie znacznie im bliższe geograficznie azjatyckie kraje postkomunistyczne. Przy tym, z państw byłego bloku wschodniego politycznie ważna dla Japonii była tylko sama Rosja. Stanowisko rządu Japonii w sprawie redukcji polskiego i węgierskiego zadłużenia zagranicznego nadawało sprawie niemal ideologiczny, pryncypialny wymiar i niezależnie od rzeczywistych zamiarów japońskich polityków, stwarzało doskonały pretekst dla nieangażowania się kapitałowego w regionie Europy Środkowo -Wschodniej. Rząd japoński odrzucał, po prostu, wszelką możliwość darowania raz zaciągniętych długów niezależnie od jakichkolwiek politycznych i ekonomicznych uzasadnień takiego kroku. Pewną rolę odegrały też przy tym, niewątpliwie, tradycje kulturowe (w Japonii bankrutujący przedsiębiorca, ,zhańbiony" niemożnością spłacenia długów, często popełnia samobójstwo).

W ślad za tą deklaracją poszło cofnięcie przyznanych w 1989 i 1990 r. gwarancji kredytowych dla Polski i Wegier. Według japońskich statystyk, wzajemny handel doznał gwałtownego załamania, choć dane polskie rysują zupełnie inny obraz (omówimy to szerzej w następnym paragrafie). Próba przełamania impasu podczas wizyty prezydenta Lecha Wałęsy w Japonii w 1994 r. nie powiodła się. Ostatecznie dopiero w listopadzie 1995 r. rząd japoński przywrócił gwarancje kredytowe, kładąc tym samym kres kryzysowi instytucjonalnemu. Jednak poprzednie zamrożenie gwarancji oraz postawa japońskich urzędników zaowocowała głęboką nieufnością ze

${ }^{10}$ „Japońsko-węgierskie stosunki polityczne", według ambasady Japonii w Budapeszcie; httri://wwwjapan-einabassy.hutEnglish/kpcs.html, 1996. strony przedstawicieli biznesu — przede wszystkim wobec Polski. Japońskie inwestycje w naszym kraju zaczęły się pojawiać na większą skalę dopiero w 1997 r., a do wykorzystania istniejących gwarancji japońskiego rząu ciagle jeszcze daleko. Sytuacja Węier, które krócej pozostawały „W niełasce" japońskiej administracji, jest daleko odmienna - ale i tam pozycja Japonii na liście największych inwestorów nie jest proporcjonalna do jej miejsca w gospodarce światowej. Atmosferę nieufności w Japonii wobec Polski najlepiej obrazuje wypowiedź Nagao Hyodo, byłego ambasadora tego kraju w Warszawie, niezwykle zasłużonego dla wzajemnych stosunków i dla przełamania omawianego kryzysu, Japończyka bardzo zafascynowanego naszym krajem. Pisze on:

„Przez pierwsze trzy lata od objęcia funkcji ambasadora w Polsce, przy każdym spotkaniu z jej przywódcami zadawano mi zawsze te same pytania: 'Dlaczego Japonia nie inwestuje w Polsce?' i 'Dlaczego Japonia przejawia wobec Polski tak wielką ostrożność?". Mówiąc szczerze, w japońskich kręgach gospodarczych z pewnością funkcjonował w tamtym okresie negatywny wizerunek Polski. Każdy przyjazd do Japonii stawiał mnie w kłopotliwej sytuacji wobec problemu ogromnej rozbieżności między rzeczywistym stanem polskiej gospodarki, a jej negatywnym postrzeganiem przez kręgi gospodarcze Japonii; mnie, pragnącego choć trochę sprostać oczekiwaniom Polski, dylemat ten niejednokrotnie przyprawiał o ból serca. Nierzadko bywało tak, że wtedy, gdy podkreślałem wspaniałe wyniki reform w Polsce, pytano mnie półżartem, czy jestem ambasadorem Japonii czy Polski ${ }^{11}$.

Jak już wspomniano, dla Japonii jedynym istotnym politycznie partnerem by (i jest) tylko lider „bloku wschodniego" — a zarazem najbliższy europejski sąsiad Japonii - Związek Sowiecki, a współcześnie Rosja. Podporządkowanie polityki japońskiej wobec Europy Środkowo-Wschodniej zasadzie ostrożności i jak najdalej idącego nie drażnienia Moskwy jest posunięciem naturalnym i łatwym do zrozumienia. Tokio bowiem niczego nie spodziewa się osiagnać w obszarze położonym między Rosją a Niemcami, gdyż gdzie indziej realizuje zasadnicze cele swojej polityki.

Japońska ostrożność wobec Rosji najlepiej ilustruje sposób w jaki Tokio uznawało niepodległość kolejnych wyzwalających się krajów byłego Związku Sowieckiego i byłej Jugosławii. Niepodległość państw bałtyckich — Litwy; Łotwy i Estonii, Japonia uznała 6 września 1991 r. Stosunki dyplomatyczne z tymi krajami Tokio nawiązało odpowiednio - 10 października 1991 r. Z Wilnem i Rygą, a w styczniu 1993 r. z Tallinem. Niepodle-

Wiadomości z Japonii, wydawnictwo Ośrodka Kultury i Informacji ambasady Japonii w nr $1 / 138$, s. 2.

${ }^{12}$ Kodansha 1995 World Yearbook, Kodansha, Tokyo 1995, s. 589. 
glość Ukrainy, Białorusi i Mołdawii została uznana 28 grudnia 1991 r. Stosunki dyplomatyczne z Mińskiem Japonia nawiązała 26 stycznia 1992 r., z Kiszyniowem 16 marca tegoż roku, a z Kijowem dopiero 2 marca 1994 r., kiedy to podpisano traktat o współpracy i handlu ${ }^{12}$.

Spośród państw byłej Jugosławii, Japonia niepodległość Słowenii i Chorwacji uznała 17 marca 1992 r. i nawiązała $\mathrm{z}$ tymi państwami stosunki dyplomatyczne odpowiednio - 12 października 1992 r. i 5 marca 1993 r Natomiast Byłą Jugosłowiańską Republikę Macedonię rząd japoński uznał 21 grudnia 1993 r., nawiązując z nią stosunki dyplomatyczne 1 marca 1994 r. ${ }^{13}$. Z Bośnią i Hercegowiną Japonia nawiązała stosunki dyplomatyczne dopiero 9 lutego 1996 r. (uznanie tego państwa nastąpiło dwa tygodnie wcześniej - 23

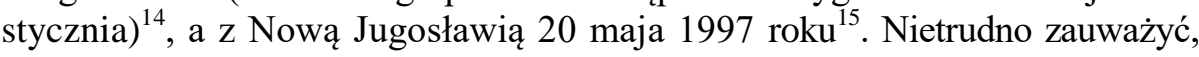
że w tym ostatnim przypadku, polityka japońska podążała za amerykańska, przyłaczajac się do nacisku Stanów Zjednoczonych na zakończenie krwawego konfliktu etnicznego. W związku z planami odbudowy Bałkanów po konflikcie w Kosowie, ponownie pojawily się oczekiwania wysokiej partycypacji finansowej Japonii w tym programie. Za wcześnie jednak, by ocenić ich realność

Japonia w wiele działań angażuje się ostrożnie i dopiero wtedy, gdy jest przekonana, że może osiągnąć założone cele. Jako członek grupy $\mathrm{G}-7$ (obecnie: $\mathrm{G}-8$ ) zaangażowała się $\mathrm{w}$ ratowanie środowiska naturalnego $\mathrm{i}$ rozbrojenie nuklearne $\mathrm{w}$ naszym regionie. Ten ostatni element jej polityki został poparty środkami finansowymi: już w kwietniu 1993 r. Japończycy zadeklarowali $100 \mathrm{mln}$ dolarów pomocy w rozbrojeniu nuklearnym państw byłego Związku Sowieckiego, a w $1995 \mathrm{r}$ wraz z innymi państwami grupy $300 \mathrm{mln}$ na likwidację elektrowni jądrowej w Czarnobylu. Ukraina domaga się jednak większych środków, wystarczających na zakończenie budowy nowych elektrowni - negocjacje w tej sprawie, zarówno z grupą $\mathrm{G}-8$, jak i, przede wszystkim, z Unią Europejską, nie zostały jeszcze zakończone.

- Jak już wspomniano powyżej, Europa Środkowa i Wschodnia zajmuje dalekie miejsce w hierarchii interesów politycznych Japonii. Stosunek Japonii do krajów naszego regionu odzwierciedla częstotliwości wizyt oficjalnych z obu stron. Japońscy politycy, jeśli już przyjeżdżają do tej części świata, czynią to najczęściej w bezpośrednim związku z podróżami do

${ }_{14}$ Tamże, s. 569, 5'79, 592

${ }^{14}$ „Establishment of Diplomatic Relations wich Bosnia and Herzegovina, Announeemant by the Press Secretary", htttp://www2.nttea.com:8010/infomofa/press/releasek.h_independent.htmE 1996.

${ }^{15}$ "Establishment of Diplomatic Relations with the Federal Republic of Yugoslavia", Litlp://www2.nttea.com:M.WinfomofatpressfreleaseW521.html 1997.
Europy Zachodniej lub (coraz rzadziej) do Rosji. W 1995 r. podróż do Chorwacji i na Węgry odbył minister spraw zagranicznych Kono. W sierpniu 1997 r. Czechy i Polska były częścią europejskiej podróży jego następcy Ikedy Yuhikiko, który kilka miesięcy wcześniej, w grudniu 1996 r., odwiedził również Sarajewo i Kijów. Wizytą szczególnego rodzaju była podróż księcia Takamady do Czech, Polski i na Węgry jesienią 1994 r. 30 listopada 1994 r. w Krakowie otworzył on uroczyście Centrum Sztuki i Techniki Japońskiej „Manggha", zbudowane przy pewnym udziale rządu Japonii (obok funduszu Andrzeja Wajdy z przyznanej mu nagrody Kyoto, jak też darów firm oraz osób prywatnych, przeznaczono również specjalny fundusz pozostały po niewykorzystanym przez Polskę kredycie żywnościowym z 1990 r.).

Politycy naszego regionu Japonię odwiedzają też rzadko. Polscy prezydenci wizytowali Tokio dwukrotnie: w 1994 r. Japonię odwiedził Lech Wałęsa, a w lutym 1998 r. Aleksander Kwaśniewski (nieoficjalnie). W Japonii oficjalne wizyty złożyli też prezydenci: Ukrainy — Leonid Kuczma (22-25 marca 1995 r). Litwy - Algirdas Brazauskas (12-15 maja 1997 r.) i Bułgarii - Peter Stojanov (listopad 1997 r.) oraz premierzy, między innymi, Czech - Vaclav Klaus (wrzesień 1996 r.) i Węgier — Gyula Horn (10-13 grudnia 1995 r.)

Warto wspomnieć, że dopiero w 1988 r. powstały w Tokio jednostki organizacyjne ministerstw: Spraw Zagranicznych oraz Przemysłu i Handlu Międzynarodowego, zajmujące się wyłącznie polityką wobec Europy Środkowej, gdyż wcześniej problematyka ta podlegała odpowiednim strukturom koordynującym stosunki ze Związkiem Sowieckim. Po jego rozpadzie, obszar kompetencji komórek do spraw Europy Środkowej został poszerzony o trzy kraje bałtyckie, które nie wstapiły do Wspólnoty Niepodległych Państw. Wszystkie pozostałe kraje byłego Związku Sowieckiego znajdują się nadal w obrębie zainteresowania rosyjskich wydziałów ministerstw japońskich.

\section{Stosunki gospodarcze}

Najbardziej intrygującym zjawiskiem w obrotach towarowych między Japonią a krajami naszego regionu jest pewnego rodzaju ,problem statystyczny". Wiarygodne źródło, jakim jest IMF Direction for Trade Statistics dla odpowiadających sobie wskaźników eksportu i importu Japonii oraz jej partnerów z obszaru Europy Środkowo Wschodniej, podaje rozbieżne dane, a różnice danych japońskich i polskich zdecydowanie przekraczają poziom zwykle występujących niewielkich rozbieżności, związa- 
nych, na przykład z przeliczaniem bazy kontraktu z CIF na FOB. Zjawisko wydaje się tym bardziej zagadkowe, że dla niektórych krajów różnice są tak wielkie, iż rysują wręcz odmiennie tendencje zachodzacych zmian.

I tak, po zamrożeniu gwarancji rządowych w 1992 r., według japońskich statystyk, eksport z Japonii do Polski uległ gwałtownemu załamaniu. Według zaś danych polskich $\mathrm{z}$ tego źródła - rozwijał się on z nie zmienioną dynamiką. O czym może świadczyć taka różnica?

Jak wiadomo, IMF układa swoja statystyke w oparciu o dane dostarczone przez kraje członkowskie, zatem Polska (podobnie jak inne kraje naszego regionu) i Japonia podawały mu rozbieżne dane, co w sposób oczywisty obrazuje odmienności obrazu naszych władz statystycznych

i gospodarczych na temat wielkości wzajemnych obrotów. Różnica ta, zapewne, mogła powstać tylko w jeden sposób: obie strony w odmienny sposób zaklasyfikowały poszczególne części swojej wymiany towarowej z zagranica. Na przykład, zwyczajem drobnych, polskich importerów jest kupowanie towarów japońskich nie bezpośrednio w tym kraju (a żaden japoński koncern nie ma jeszcze własnej, dobrze rozwiniętej sieci sprzedaży w Polsce, porównywalnej choćby z siecią koreańskiego Daewoo), lecz w Singapurze, czy Bangkoku. Drobni polscy importerzy z zasady nie są bowiem w stanie sprostać wysokim wymaganiom dotyczącym wiarygodności ( $w$ tym kredytowej) stawianym przez japońskie koncerny. Kupcy ci jednak zgłaszają polskim władzom celnym towary jako ,japońskie", a nie singapurskie czy tajskie. Natomiast dla Japończyków pozostaje to eksportem do Singapuru czy Tajlandii, a nie do Polski. Podobnie postępują handlowcy z Chorwacji, Słowenii czy Estonii - wszędzie tam, gdzie upadły działajace poprzednio centrale handlu zagranicznego, posiadające własne, ustalone kontakty w Japonii.

Natomiast na Węgrzech i Ukrainie nadal zachowana została stara struktura handlu zagranicznego, zdominowana przez wielkie firmy —obecnie już, przynajmniej na Węgrzech, sprywatyzowane. Łatwiej jest im dokonywać zakupów bezpośrednio w Japonii, niż korzystać z pośrednictwa firm Azji Południowe Wschodniej. W tych krajach nie występuja więc różnice danych statystycznych, bądź też mieszcza się one $\mathrm{w}$ granicach właściwych ze względu na odmienną bazę ceny, w której liczy się eksport i import ${ }^{16}$
Japoński eksport do krajów Europy Środkowej i Wschodniej (w mIn USD, ceny bieżące na bazie FOB), w nawiasach dane kraju — importera na bazie CIF - w zestawieniu ogólnym dane importerów podliczono dla ilustracji skali zjawiska

\begin{tabular}{|c|c|c|c|c|c|c|c|}
\hline Kraj & 1990 & 1991 & 1992 & 1993 & 1994 & 1995 & 1996 \\
\hline Albania & 1 & - & - & 2 & - & 2 & 1 \\
\hline Białoruś & - & - & $-(8)$ & $5(9)$ & $47(8)$ & $6(22)$ & $3(7)$ \\
\hline Bośnia i Hercegowina & - & - & - & - & - & - & 1 \\
\hline Bulgaria & 54 & 36 & $37(83)$ & 30 & 20 & 16 & 17 \\
\hline Chorwacja & - & - & - & $11(42)$ & $9(30)$ & $12(61)$ & $10(105)$ \\
\hline Czechy & - & - & - & - (214) & $\begin{array}{c}125 \\
(305) \\
\end{array}$ & $\begin{array}{c}141 \\
(365) \\
\end{array}$ & $\begin{array}{c}189 \\
(477) \\
\end{array}$ \\
\hline Czechosłowacja & 52 & $\begin{array}{c}69 \\
(121)\end{array}$ & 173 & - & - & - & - \\
\hline Estonia & - & - & $-(2)$ & 7 (38) & $5(48)$ & $10(47)$ & $8(65)$ \\
\hline Jugosławia & $\begin{array}{c}252 \\
(425)\end{array}$ & $\begin{array}{c}176 \\
(336)\end{array}$ & 36 & & & & \\
\hline Nowa Jugosławia & - & - & - & - & - & 1 & 2 \\
\hline Litwa & - & - & $-(4)$ & 9 & 5 & 5 & 8 \\
\hline Lotwa & - & - & $-(6)$ & 2 & 13 & $3(10)$ & 3 \\
\hline Macedonia & - & - & - & $-(\mathbf{1 0})$ & $2(13)$ & $3(15)$ & 9 \\
\hline Mołdawia & - & - & - & - & - & $-(1)$ & \\
\hline Polska & $\begin{array}{c}309 \\
(207)\end{array}$ & $\begin{array}{c}361 \\
(276)\end{array}$ & $\begin{array}{c}238 \\
(320) \\
\end{array}$ & $\begin{array}{c}152 \\
(330)\end{array}$ & $\begin{array}{c}118 \\
(351)\end{array}$ & $\begin{array}{c}170 \\
(479) \\
\end{array}$ & $\begin{array}{c}219 \\
(605) \\
\end{array}$ \\
\hline Rumunia & 82 & 57 & $30(72)$ & $28(52)$ & $29(53)$ & $42(70)$ & $47(87)$ \\
\hline Slowacja & - & - & - & $-(\mathbf{7 3})$ & $10(82)$ & $\begin{array}{c}14 \\
(131) \\
\end{array}$ & $\begin{array}{c}18 \\
(189) \\
\end{array}$ \\
\hline Slowenia & - & - & - & $\begin{array}{c}26 \\
(125)\end{array}$ & $\begin{array}{c}26 \\
(125)\end{array}$ & $\begin{array}{c}46 \\
(156)\end{array}$ & $\begin{array}{c}47 \\
(162)\end{array}$ \\
\hline Ukraina & - & - & - & 62 & 48 & 39 & 60 \\
\hline Węgry & 143 & 225 & 239 & 280 & 264 & 350 & 376 \\
\hline Ogólem & $\begin{array}{c}892 \\
(790) \\
\end{array}$ & $\begin{array}{c}924 \\
(1051) \\
\end{array}$ & $\begin{array}{c}753 \\
(943) \\
\end{array}$ & $\begin{array}{c}694 \\
(1278)\end{array}$ & \begin{tabular}{|c|}
721 \\
$(1365)$
\end{tabular} & $\begin{array}{c}860 \\
(1898) \\
\end{array}$ & $\begin{array}{c}1018 \\
(2190) \\
\end{array}$ \\
\hline $\begin{array}{l}\text { Udzial regionu } \\
\text { w japońskim } \\
\text { eksporcie (w procentach) }\end{array}$ & 0,28 & $\mathbf{0 , 2 7}$ & 0,22 & 0,17 & 0,17 & 0,18 & 0,22 \\
\hline
\end{tabular}

${ }^{16}$ Wszystkie dane za: IMF Direetion for Trade Statisties, 1997. 
W przypadku japońskiego importu z krajów naszego regionu, nie występują tego rodzaju różnice. Jak można sądzić bowiem, japońskie koncerny dokonują bezpośrednio zakupów na miejscu, a pośrednicy nie odgrywaja większej roli w lokowaniu naszych towarów na rynku japońskim. Wydaje się, że spore możliwości rozwoju eksportu do Japonii (który wobec istniejącej nierównowagi wymiany należało by zwiększyć) pojawiłyby sie przy zmianie jego organizacji: gdyby polskie firmy były obecne na japońskim rynku i umiały uwzględnić (na miarę swoich możliwości finansowych) jego specyfikę kulturową, być może sprzedaż i współpracę dałoby się rozszerzyć. Może to dotyczyć także sfery kreowania wszelkiego rodzaju software.

Japoński import z krajów Europy Środkowej i Wschodniej

(w mln USD, ceny bieżące CIF)

\begin{tabular}{|l|c|c|c|c|c|c|c||}
\hline Kraj & 1990 & 1991 & 1992 & 1993 & 1994 & 1995 & 1996 \\
\hline Albania & 10 & 8 & 5 & 3 & 1 & 3 & 5 \\
\hline Białoruś & - & - & - & 5 & 4 & 12 & 14 \\
\hline Bośnia i Hercegowina & - & - & - & - & - & - & 3 \\
\hline Chorwacja & - & - & - & 2 & 3 & 3 & 3 \\
\hline Czechy & - & - & - & - & 96 & 116 & 126 \\
\hline Czechosłowacja & 129 & 126 & 134 & - & - & - & - \\
\hline Estonia & - & - & - & 7 & 16 & 14 & 18 \\
\hline Jugosławia & 61 & 73 & 40 & - & - & - & - \\
\hline Nowa Jugosławia & - & - & - & - & - & - & 1 \\
\hline Litwa & - & - & 37 & 36 & 42 & 22 \\
\hline Łotwa & - & - & 16 & 19 & 20 & 9 & 7 \\
\hline Macedonia & - & - & - & 14 & 9 & 6 & 8 \\
\hline Mołdawia & - & - & - & 1 & - & - & - \\
\hline Polska & 185 & 190 & 159 & 97 & 67 & 85 & 90 \\
\hline Rumunia & 86 & 94 & 79 & 70 & 61 & 60 & 50 \\
\hline Słowacja & - & - & - & 6 & 8 & 26 & 22 \\
\hline Słowenia & - & - & - & 33 & 28 & 32 & 29 \\
\hline Ukraina & - & - & - & 106 & 79 & 123 & 143 \\
\hline Węgry & 147 & 150 & 126 & 116 & 119 & 125 & 156 \\
\hline Ogółem & 653 & 686 & 602 & 540 & 570 & 686 & 727 \\
\hline $\begin{array}{l}\text { Udział regionu w japońskim } \\
\text { imporcie (w procentach) }\end{array}$ & 0,22 & 0,29 & 0,26 & 0,22 & 0,20 & 0,20 & 0,20 \\
\hline $\begin{array}{l}\text { Nadwyżka japońskiego } \\
\text { eksportu (w mln USD) }\end{array}$ & 239 & 238 & 151 & 154 & 151 & 174 & 291 \\
\hline
\end{tabular}

\begin{tabular}{|l|c|c|c|c|c|c|c|}
\hline & 1990 & 1991 & 1992 & 1993 & 1994 & 1995 & 1996 \\
\hline $\begin{array}{l}\text { Ta sama nadwyżka } \\
\text { po uwzględnieniu } \\
\text { danych importerów }\end{array}$ & 137 & 364 & 341 & 738 & 795 & 1212 & 1463 \\
\hline
\end{tabular}

Ujemny bilans w obrotach towarowych z Japonią posiada większość krajów świata. Niepokoi jednak, że w przypadku Europy Środkowej i Wschodniej ten bilans nie jest wyrównywany przez napływ japońskiego kapitału. Wielkość japońskich inwestycji bezpośrednich w zestawieniu z zagranicznymi inwestycjami bezpośrednimi ogółem w tych krajach, pozwała ocenić rozmiar japońskiego zaangażowania. A choć dane - uzyskane droga elektroniczną z Japońskiej Organizacji Handlu Zagranicznego — różnić się moga od przedstawianych przez rodzime urzędy statystyczne właściwych krajów, to jednak nie zmienia to istoty samego zjawiska, jakim jest nikłe zainteresowanie japońskiego kapitału tą częścią świata.

Zrealizowane, bezpośrednie inwestycje japońskie w krajach

Europy Środkowo Wschodniej do zagranicznych inwestycji bezpośrednich w tych krajach ogólem (w mln USD, w cenach bieżących)

\begin{tabular}{|c|c|c|c|c|c|c|c|c|c|}
\hline Kraj & Inwestycje & 1990 & 1991 & 1992 & 1993 & 1994 & 1995 & 1996 & \begin{tabular}{|c|}
$199 ?$ \\
(I. poł.)
\end{tabular} \\
\hline Bułgaria & \begin{tabular}{|l} 
japońskie \\
Ogółem
\end{tabular} & br.d. & br.d. & $\begin{array}{c}- \\
34 \\
\end{array}$ & $\begin{array}{c}- \\
100 \\
\end{array}$ & 211 & $\begin{array}{c}- \\
163 \\
\end{array}$ & $\begin{array}{r}- \\
283 \\
\end{array}$ & $\begin{array}{c}- \\
413 \\
\end{array}$ \\
\hline Czechy & \begin{tabular}{|l} 
japońskie \\
Ogółem
\end{tabular} & - & $\begin{array}{l}- \\
523 \\
\end{array}$ & $\begin{array}{c}4 \\
1003\end{array}$ & $\begin{array}{c}7 \\
568 \\
\end{array}$ & $\begin{array}{c}- \\
862 \\
\end{array}$ & $\begin{array}{c}46 \\
2559\end{array}$ & $\begin{array}{c}2 \\
1428\end{array}$ & \\
\hline Polska & $\begin{array}{l}\text { japońskie } \\
\text { Ogółem }\end{array}$ & $\begin{array}{c}3 \\
100 \\
\end{array}$ & $\begin{array}{c}2 \\
300 \\
\end{array}$ & $\begin{array}{c}0 \\
978 \\
\end{array}$ & $\begin{array}{c}7 \\
1563 \\
\end{array}$ & $\begin{array}{c}3 \\
1280 \\
\end{array}$ & $\begin{array}{c}3 \\
2511 \\
\end{array}$ & $\begin{array}{c}10 \\
5196 \\
\end{array}$ & $\begin{array}{r}13 \\
1931 \\
\end{array}$ \\
\hline Rumunia & $\begin{array}{l}\text { japońskie } \\
\text { Ogółem }\end{array}$ & $\begin{array}{c}- \\
107\end{array}$ & $\begin{array}{l}0 \\
149\end{array}$ & $\begin{array}{l}- \\
307\end{array}$ & $\begin{array}{c}- \\
156\end{array}$ & $\begin{array}{l}- \\
568\end{array}$ & $\begin{array}{r}2 \\
313\end{array}$ & $\begin{array}{r}5 \\
609\end{array}$ & $\begin{array}{c}5 \\
\text { br.d. }\end{array}$ \\
\hline Słowacja & \begin{tabular}{|l|} 
japońskie \\
Ogólem
\end{tabular} & $\begin{array}{c}- \\
\text { br.d. }\end{array}$ & $\begin{array}{c}- \\
83\end{array}$ & $\begin{array}{c}- \\
137 \\
\end{array}$ & $\begin{array}{c}- \\
146 \\
\end{array}$ & $\begin{array}{c}1 \\
186 \\
\end{array}$ & $\begin{array}{r}4 \\
181 \\
\end{array}$ & $\begin{array}{r}4 \\
154 \\
\end{array}$ & $\begin{array}{l}\text { brd. } \\
\text { br.d. }\end{array}$ \\
\hline Węgry & \begin{tabular}{|l} 
japońskie \\
Ogółem
\end{tabular} & $\begin{array}{r}29 \\
900\end{array}$ & $\begin{array}{r}181 \\
1614\end{array}$ & $\begin{array}{c}4 \\
1641\end{array}$ & $\begin{array}{c}72 \\
2481\end{array}$ & $\begin{array}{c}41 \\
1320\end{array}$ & $\begin{array}{c}33 \\
4570\end{array}$ & $\begin{array}{c}13 \\
2524\end{array}$ & $\begin{array}{r}42 \\
1450\end{array}$ \\
\hline $\begin{array}{l}\text { Zrealizowane inwe } \\
\text { ogółem }\end{array}$ & tycje & 1506 & 2924 & 4595 & 5505 & 5169 & 10935 & 9288 & br.d. \\
\hline W tym japońskie & & 32 & 183 & 8 & 86 & 45 & 88 & 34 & 72 \\
\hline
\end{tabular}

${ }^{17}$ Według The Vienna histitute for Comparative Economic Studies, Statistics notified to the Japanese Ministry of Finance, za:

http://www.jetro.go.jp/WHITEPAPER/Invest98/f51.html, 1998. 
Tak w przypadku napływu japońskich inwestycji, jak w przypadku eksportu krajów naszego regionu na rynek japoński, sankcje japońskiego rządu z 1992 r. były istotnym czynnikiem hamującym. Nie miały one natomiast wielkiego znaczenia (po uwzględnieniu danych nie zarejestrowanych przez strone japońską) dla wzrostu naszego importu z Japonii, który zdaje się posiadać stała, niezależna od wpływów zewnętrznych, dynamikę. Jak się zdaje, wynika ona przede wszystkim ze zmian w strukturze konsumpcji w krajach naszego regionu i dokonującego się w nich awansu cywilizacyjnego właśnie $\mathrm{w}$ tej sferze. Wiąże się on $\mathrm{z}$ rosnącym popytem na prestiżowe dobra trwale pochodzące z Japonii, takie jak samochody, sprzęt audiowizualny czy komputery.

Wśród inwestorów japońskich największym zaufaniem ciesza się jak dotą Węgry, jednak nowe projekty, których nie uwzględniła powyższa statystyka, realizowane sa obecnie raczej w Czechach i w Polsce. Byłe, europejskie republiki sowieckie nie budzą natomiast zainteresowania japońskiego kapitału niemal wcale. $\mathrm{O}$ ile więc - podobnie jak gierkowska ekipa lat siedemdziesiątych — rządy i społeczeństwa krajów wyzwalających się spod panowania reżimów komunistycznych naszej części świata liczyły na duży rozwój współpracy gospodarczej z Japonią, pragnienie to nie zostało na razie zrealizowane i w perspektywie pogłębiającego się kryzysu w tym kraju, nie ma szans na rychłe urzeczywistnienie. Co jest więc $w$ istocie podstawą stosunków Japonii z Europa Środkowo Wschodnią?

Wydaje się, że w minionym okresie były to głównie stosunki kulturalne. Omówienie zakresu współpracy w dziedzinie kultury między Europa Środkowa i Wschodnią a Japonią, przekraczałoby ramy tego studium. Wspomnieć jednak trzeba, że w każdym $\mathrm{z}$ państw naszego regionu istnieją ośrodki zajmujące się wymianą kulturalną i naukowo-techniczną z Japonią. Wydaje się, że Polska w tej wymianie zajmuje priorytetowe miejsce, rola szczególna zaś przypada warszawskiej japonistyce, najstarszej w regionie, bo liczącej już 80 lat. Pewien wpływ na rozszerzenie kontaktów z Japonią ma rozwój ruchu turystycznego. Promowaniu turystyki ma służyć zniesienie wiz dla niektórych krajów naszego regionu. Wegry były pierwszym państwem regionu, z którym Japonia podpisała umowę o ruchu bezwizowym. Polska była następnym.

Dobrze rozwijająca się współpraca kulturalna państw naszego regionu z Japonią wynika, ze wspomnianej już na początku artykułu, fascynacji Japonią jej historią i kulturą. Dotyczy to nie tylko naszego regionu, bo Japonią fascynuje się zarówno Europa jak i Ameryka. To zainteresowanie Japonia świadomie wykorzystuje. Po wprowadzeniu na rynki światowe samochodów elektroniki, Japonia niezwykle szybko rozwija produkcję software obejmującego wytwarzanie i przetwarzanie nie tylko programów komputerowych, ale i filmów, muzyki czy mody. W japońskich firmach softwarowych, na przykład, w firmie Nintendo, zatrudnionych jest wielu programistów z Węgier i Polski.

Kraje Europy Środkowej i Wschodniej, po destrukcyjnym dla struktur narodowych tożsamości okresie komunistycznej dyktatury, znajdują się w trudnym okresie poszukiwania nowej identyfikacji zbiorowej. Rozdzierane niszczone w chwili obecnej waśniami etnicznymi Bałkany stają też przed taką koniecznością $\mathrm{W}$ miarę normalizowania się sytuacji poszczególnych krajów. Przykład Japonii, która zdołała obronić swoje tradycje, o czym wspomniano już na wstepie, mógłby stać się dla nich inspirujacy, co pogłębić by mogło współpracę kulturalną, a dopiero wraz z jej rozwojem - zainteresowania naszym regionem japońskich kręgów gospodarczych.

\section{Wnioski końcowe}

Zarysowany powyżej obraz najnowszych stosunków Japonii z regionem Europy Środkowej i Wschodniej nie jest, oczywiście, pełny. Jego najistotniejszym brakiem jest pominięcie tu sfery kultury i nauki, szczególnie zaś dosyć rozwiniętych badań porównawczych zagadnień transformacji ustrojowej, ważnych dla Japonii, gdyż dotyczą one także, choć w bardzo odmiennej formie, Azji Wschodniej (Chin, Wietnamu, a potencjalnie i Korei Północnej, bardzo niepokojącej Japończyków). Główne obszary wzajemnych kontaktów oficjalnych wiążą się głównie z zaangażowaniem w sprawy polityki światowej, często związanym $\mathrm{z}$ działalnością na forum organizacji międzynarodowych Dodać warto, że japońska aktywność w tej dziedzinie przynosi znacznie lepsze efekty w Europie Środkowej ${ }^{18}$ niż wśród jej najbliższych sąsiadów, pamiętających jeszcze wojnę na Pacyfiku. Deklaracje dobrej woli w rozwijaniu współpracy, składane na forum ONZ i przy wizytach oficjalnych, zbyt łatwo są traktowane przez partnerów z naszej części Europy jako realne szanse współpracy. Tymczasem, o czym zwolennicy „budowy drugiej Japonii" zdaja się nie pamiętać, polityką w dalszym ciągu rządzą głównie interesy, nie tylko zresztą gospodarcze, zaś w tej dziedzinie nasz region dla Japonii nie jest znaczący.

Od 1991 r. profesor Sadako Ogata była Wysokim Komisarzem do spraw Uchodźców, a wysokim urzędnikiem tej organizacji w Sarajewie przez długi czas była Izumi Nakamistu. Japonia wielokrotnie dofinansowywała Biuro Komisarza, na przykład, minister spraw zagranicznych Yohei Kono podczas wizyty w Zagrzebiu wiosna 1995 r. obiecał przeznaczyc a ten cel 25 mln 850 tys. dol., a w grudniu Zego samo rencji na temat wprowadzenia w życie porozumienia z Dayton, nastepne $20 \mathrm{mln}$ dol. 
Tam gdzie interesy Japonii i Polski, czy innych krajów regionu, pozostają zbieżne, rząd japoński w zasadzie przychylny jest naszym postulatom - i japońskie poparcie dla członkostwa Polski w OECD jest tego najlepszym przykładem.

Analizując stosunki Japonii z krajami Europy Środkowo Wschodniej daje się zauważyć, że cechuje je nierównowaga oczekiwań i możliwości, która jest przede wszystkim pochodna przyjętej przez Japonie strategii polityki zagranicznej, a strategię tę dyktuje jej własne położenie geopolityczne i geoekonomiczne. Ponieważ zaś jedno i drugie może się zmieniać wraz ze zmiana układu sił $\mathrm{w}$ świecie, niewykluczone jest pojawienie się w przyszłości nowych potrzeb, a w rezultacie i wypracowania nowej strategii w polityce japońskiej, dopiero wtedy Europa Srodkowa mogłaby stać się istotniejszym polem gry lub sprzymierzeńcem. 